Portland State University

PDXScholar

\title{
An Evaluation of the Federal Legal Services Program: Evidence from Crime Rates and Property Values
}

Jamein P. Cunningham

Portland State University, janein.cunningham@pdx.edu

Follow this and additional works at: https://pdxscholar.library.pdx.edu/econ_fac

Part of the Criminal Law Commons, Criminology Commons, Law and Economics Commons, Law Enforcement and Corrections Commons, Legal Profession Commons, and the Social Control, Law, Crime, and Deviance Commons

Let us know how access to this document benefits you.

\section{Citation Details}

Cunningham, J. P. (2016). An evaluation of the Federal Legal Services Program: Evidence from crime rates and property values. Journal of Urban Economics, 92, 76-90.

This Post-Print is brought to you for free and open access. It has been accepted for inclusion in Economics Faculty Publications and Presentations by an authorized administrator of PDXScholar. Please contact us if we can make this document more accessible: pdxscholar@pdx.edu. 


\title{
An Evaluation of the FEDERAL LEGAL SERVICES PROGRAM: EVIDENCE FROM CRIME RATES AND PROPERTY VALUES
}

\author{
March 2015 \\ Jamein P. Cunningham \\ Department of Economics \\ Portland State University
}

\begin{abstract}
$\underline{\text { Abstract }}$
This paper uses the city level roll-out of legal service grants to evaluate their effects on crime. Using Uniform Crime Reports from 1960 to 1985, the results show that there is a short run increase of 7 percent in crimes reported and also a 13 percent increase in crimes cleared by arrest. Results show an increase in the staffing of police officers in cities that received legal services. These cities are also associated with having higher median property values 10 years later. This supports the narrative that legal services changed police behavior through litigation or threats of litigation.
\end{abstract}

Contact Information:

Department of Economics, Portland State University, 1721 SW Broadway, Portland, Oregon 97201; jamein.cunningham@pdx.edu; (503) - 725 - 3934

Acknowledgements:

This project was generously supported by an NICHD center grant to the Population Studies Center at the University of Michigan (R24 HD041028). I am grateful to William Collins and Robert Margo for sharing the riot data for the 1964 to 1971 period. I am also grateful for helpful comments from Andrew Goodman-Bacon, Martha Bailey, John Bound, Charlie Brown, Tanya Byker, Sheldon Danziger, Nic Duquette, Thomas Ehrlich, John Gallup, Mary King, Patrick Mason, Ryan Monarch, Sam Myers and Mel Stephens. 
"Legal Services Lawyers have won the confidence of angry young men and women and have channeled their grievances into democratic procedures. This capability and achievement mark a major victory for those concerned with maintaining law and order."

- From the Office of Economic Opportunity, November 1969 Senate Hearing

"You can carry a machete through the streets of Newark and not get locked up"

- Mr. Kowalewski, New York Times 1967

After decades of decline, reported crime in the United States began to rise in the early 1960s. The rise in violent crime, especially homicide, pushed crime to the forefront of political debates (Grimes \& Loo 2004). Accompanying the rise in crime, was a series of civil demonstrations that escalated into wide spread riots during the summer of 1964. Riots in Harlem, Rochester, and Philadelphia presented political obstacles for launching President Johnson's War on Poverty. ${ }^{1}$ Relatedly, the response of law and order to riots and rioters created more tension between blacks in urban areas and local police officers (O'Reilly, 1988). Concerns over the decline of urban communities and eruptions of urban violence resulted in the inclusion of experimental programs within the War on Poverty that would reduce the likelihood of riots.

In 1965 the Neighborhood Legal Services Program (LSP) was introduced to provide the poor with legal channels to remediate grievances, especially those resulting in riots (Gillette, 1996). ${ }^{2}$ Historically, the poor had limited access to legal institutions due to financial constraints and discrimination. Many viewed the lack of legal recourse produced demonstrations that escalated into riots in poor

\footnotetext{
${ }^{1}$ Riots occurred in Harlem and Rochester in July of 1964 and in Philadelphia in August of 1964. The Economic Opportunity Act was signed into law in August of 1964.

${ }^{2}$ The Legal Services Program was not included in the initial introduction of programs under the War on Poverty.
} 
black communities. In response, the LSP was mandated to facilitate better relationships between the bureaucracies and the poor that they affected.

The legal services program was introduced with an annual budget of 20 million dollars and by 1975 there existed over 600 offices with a budget over 70 million dollars. Although the size and scope of the program has gone through many changes, it still exists as the Legal Services Corporation. As of 2013, there are over 800 offices located in fifty states with an annual program budget of 365 million dollars. ${ }^{3}$ Donald Baker, chief counsel of the Office of Economic Opportunity believed that the LSP would "have more impact on the total structure of our social, economic, and political structures than anything else that OEO and perhaps even the federal government has done on the domestic scene." However, despite over 50 years of operations, little can be said about the actual impact of the program. This is in part due to lack of data on the users of the LSP, and to a greater extant, the lack of convincing measures of legal services themselves. Pertinent questions remain to be answered: did the LSP mitigate the urban decline that occurred as a result of racial riots in the 1960s? Did the LSP improve the welfare of the poor?

This paper is the first to quantitatively evaluate the impact of the LSP on the quality of life of the poor. I use newly collected data on the communities receiving legal service grants between 1965 and 1975, and I focus on crime as a measurement of quality of life for several reasons. First, crime captures actions that negatively affect individual welfare, including threats to individual safety and personal property. Second, crime is one of the few measures of well-being consistently recorded over time at the city level for the period of interest. Lastly, crime was an outcome linked to the LSP by advocates and opponents. In addition to crime rates, I provide evidence of the impact of the LSP on other measures of

\footnotetext{
${ }^{3}$ Information provided by the Legal Service Corporation 2013 Annual Report

${ }^{4}$ See Gillette (1996)
} 
welfare, such as property values. Past literature has shown property values to be negatively related to crime (Pope \& Pope, 2010). More so, the evaluation of property values sheds light on the influence of the legal service program on riots and urban decline.

My research design takes advantage of the differential timing of the LSP implementation in cities across the United States and uses a before and after design to analyze changes in outcomes after the establishment of the LSP. I use an event-study framework (Jacobson et al. 1993) which provides a statistical description of the evolution of pre-trends in outcomes as well as the dynamics of changes after the program began. My results show that there is a short run increase in criminal offenses reported and offenses cleared by arrest after LSP grants are received. Cities that receive LSP grants are associated with a 7 percent increase in the number of crimes reported and a 13 percent increase in offenses cleared by arrest 3 years after a grant is received. After 4 years, reported crime and arrests decrease and evolve similarly to untreated cities.

These findings may reflect two different phenomena: an increase in actual crime (consistent with critics and the second quote above) or an increase in the reporting of crime (consistent with advocates and first quote above). Although it is difficult to disentangle changes in crime versus changes in reporting, the eventstudy specification provides insight into the evolution of crime after the LSP was established. The intertemporal response of crime and arrest after LSP is implemented displays an immediate increase in reported crime and arrest followed by a large decrease in reported crime. This hump-shape response is consistent with an increase in reporting followed by a decrease in actual crime. This is similar to Levitt's (1998) emphasis on changes in reporting behavior due to changes in likelihood that a crime will be solved. Second, there is an immediate increase in the staffing of police officers in cities that received federally funded legal services which has been shown to be inversely related to 
crime (Levitt 1997, 2002, McCrary 2002, 2013). Third, consistent with changes in police effort, I find that the increase in arrests is twice as large as the increase in reported crime.

Additional evidence is also consistent with legal services programs increasing social capital and improving welfare. I provide evidence of a positive relationship between the LSPs and property values. Collin and Margo (2007) showed that the median property values for black owned owners as well as all residents within a city were negatively affected by the 1960s race riots. My results support their finding as well as shows that places that received legal services in the 1960s and 1970s had higher property values in 1980 relative to cities that never received legal services. According to my results, race riots decreased property values by 6 percent and legal service increased property values by 3 percent. Furthermore, locations that received legal services earlier had higher property values in 1980 relative to those that received legal services later in the sample period. This final piece of evidence is consistent with LSPs mitigating the consequences of riots that reduced the quality of life inner city neighborhoods and contributed to improving the well-being of the poor.

Evaluations of social policies from the War on Poverty provides important information about short and long term effect that can guide contemporary crime and riot prevention policies. Citizens in poor communities historically have had negative interactions with law enforcements and the Legal Service Program was a policy intervention that had success with changing police and community behavior. Equally important, the legal service program provides a unique case study where a policy intervention provided impoverished groups additional security or access by ensuring that their legal rights were protected. Intuitively, this protection does not only work to correct market inefficiencies but also increases demand for goods the poor previously lack access to. By increasing access to welfare, housing, and proper police services, the poor indirectly benefits 
from the reduction in the cost of lawyers. For example, one expression of market inefficiency is the severe under reporting of crime. Myers (1980) finds that the actual crime rates between 1970 and 1974 were 1.5 to 3 times larger than reported crime. If some criminal offenses are under-reported due to lack of institutional responsibility or the victim perception of institutional responsibility, legal services would work to increase the number of crimes reported. ${ }^{5}$ Furthermore, the evaluation of the legal service program does not only provide an historical application of public policy but also fits into a larger literature in economics of evaluating social programs from the Great Society (Almond, Hoynes, and Schanzenbach 2011; Bailey and Goodman-Bacon 2013; Hoynes and Schanzebach 2006; Ludwig and Miller 2007).

\section{Brief History of Legal Services Under the War On Poverty}

\section{A. Empowerment of the Poor through Legal Services}

The Federal Legal Services Program was motivated by an influential journal article by Jean and Edgar Cahn, which called for the "civilian perspective" to be incorporated in the War on Poverty (Cahn \& Cahn, 1964). The Cahns' proposal was concerned with the potential of large bureaucracies generating monopoly power, concluding that the only way to protect the true interest of the poor was to provide them with accessible legal representation. Giving the poor the ability to criticize, dissent, and compel responsiveness of local institutions would allow the poor to participate in helping themselves.

The Cahns' proposed that university-affiliated, neighborhood law firms be established to serve as intermediaries between the community and those administering social programs. The law firms would provide professionals to aid in developing and stimulating leadership through opportunity, orientation, and

\footnotetext{
${ }^{5}$ Legal services lawyers have been seen as improving relationships between the community and the police. Many encounters of how the LSP have influenced behavior of local institutions are documented in congress subcommittee meetings between 1965 to 1974.
} 
training. Each law firm would be staffed with lawyers, research assistants, and investigators with the goal of making public officials and private businesses more responsive to the needs of the poor. Legal representation would be available for divorce, eviction, welfare fraud, police brutality, installment buying, and destroying the momentum of a "militant community effort."6 The Cahns" proposed that neighborhood law firms provide legal advocacy and legal analyses in four arenas: traditional legal assistance, law reform, law advocacy, and community outreach.

Largely in response to the Cahns' ideas, the Office of Economic Opportunity (OEO) launched the Neighborhood Legal Services Program as part of the Community Action Program (CAP). Federal legal services grants went directly to community organizations and excluded local and state authorities, allowing federal funds to be spent rapidly. The OEO delegated the choice of whether a local legal aid organization would run a Legal Services Project to local Community Action Agencies (CAA). ${ }^{7}$ Implicitly, location and timing of these grants also were dependent on local political pressure and support from the local bar association. Often, differences between the CAA and local bar associations generated confusion about where and when LSPs were established. Once the National Bar Association fully backed the LSP, there was a greater effort to fund as many legal services grants as possible. ${ }^{8}$ This process, in which local bars and

\footnotetext{
${ }^{6}$ The deterrence of "militant community effort" refers to the availability of a lawyer to provide avenues for differences between the poor and various entities to use the political and judicial establishments to solve problems peacefully. Proponents of Federally Funded Legal Services often boast of their success with ending or resolving differences that resulted in riots.

${ }^{7}$ The OEO was responsible for the antipoverty programs and one of the largest initiatives was the Community Action Programs (CAP). Community Action Programs are the bread and butter of the Anti-poverty movement.

${ }^{8}$ It took two years for federally funded legal services to be fully operational due to opposition from local bar associations. The American Bar Association pledged full cooperation on February 8, 1965.
} 
community action agencies influenced funding, resulted in a wide time variation of the establishment of the LSP in various cities (Johnson, 1974).

The first year of legal services under OEO resulted in over 155 grants being issued. The annual budget during the first year was 20 million, an amount that steadily increased each fiscal year. In the second year, the budget for federally funded legal services was double the budget of the legal aid societies affiliated with the National Legal Aid Defender Association. In 1967, the legal services program doubled in size, issuing over 300 grants with a budget of over 40 million dollars. By the end of 1967, the Federal LSP was funding 250 projects and providing legal assistance in 48 states.

To gain a better understanding of how legal services funds were utilized, during the 1968 fiscal year a total of 282,000 cases were accepted. Cases involving family problems - i.e. divorce, nonsupport, and paternity - represented nearly 40 percent of the cases. Criminal and juvenile cases were responsible for over 18 percent of the cases. ${ }^{9}$ Administrative cases, which include cases that challenge laws and policies for welfare recipients and low skilled workers, accounted for only 7 percent of the total cases but were very effective. A single administrative case potentially affected thousands of residents in a city, state, or across the country. These cases usually involved challenging governmental agencies such as state and local welfare, social security, workman's compensation, and unemployment insurance. It must also be noted that neighborhood law firms could have had many indirect effects. The availability of legal assistance may result in changes in business practice, educational disciplinary responses, and police policies even without litigation or long after litigation is resolved.

\section{B. Federally-Funded Legal Services and Crime}

\footnotetext{
${ }^{9}$ See Levitan (1969) for more information on the utilization of legal service grants.
} 
The OEO funded neighborhood law firms were responsible for providing legal assistance in civil cases for individuals who were unable to afford private attorneys. Legal representation in criminal matters was provided by the state, however, these services were not always deemed as high quality. ${ }^{10}$ Legal services lawyers provided some form of legal assistance for alleged criminals when lawyers deemed that the state could not adequately represent clients with compelling cases. Also, LSP lawyers were often called upon to provide pamphlets or information concerning citizen's legal rights when interacting with the police.

In addition, opponents of the program often criticized attorneys for inciting riots and emboldening criminals by providing them with legal counsel. Police officers in Newark and Los Angeles accused LSP lawyers of organizing demonstrations and creating civil unrest. Legal Services in Venice, California was accused by local police officers of "supporting anti-police militants" and organizing citizens into "revolutionary forces". Legal services in Chicago petitioned for pardons for citizens involved in riots in 1968. Senator Murphy of California accused the California Rural Legal Services Agency of representing known criminals. Aligned with this was the narrative that, if LSP lawyers were successful at representing alleged criminals or improving the "quality" of criminals, crime would increase in these cities due to the lack of arrests and convictions. ${ }^{11}$

Another mandate of the LSP was to build community relationships with public institutions such as the police department. Within this mandate to LSPs, public institutions were to be held responsible for services rendered on behalf of

\footnotetext{
${ }^{10}$ Gideon v Wainwright (1963) ruled that state courts are required to provide an attorney for criminal defendants who were unable to afford an attorney from a private law firm.

${ }^{11}$ This was often a discretionary decision with local political consequences. Lawyers were compelled to represent clients when they felt the state would not adequately provide a proper defense for someone the lawyer deemed innocent or wronged by the police.
} 
the poor. Most legal services cases in this arena were dealt with by conferences, threats of litigation, and educating clients of legal rights and procedures. For example, legal services lawyers in Los Angeles brought a lawsuit on behalf of the black community against the Los Angeles Police Department citing them with illegal police behavior and harassment. Similar lawsuits were filed in Cleveland, Washington D.C, and Camden. The goal of these lawsuits were to change police practices, implement training in areas of race and poverty, and for recruitment of more officers - particularly minority police officers. Also in New York, Legal Services filed suit against the New York Police Department on behalf of twelve women who were victims of domestic violence. The objective of the lawsuit was to enforce the requirement that local police officials follow laws and procedures for domestic violence cases that were already in place. Similar motions were made on behalf of domestic violence victims from legal services agencies in Florida, California, Oregon, and Vermont. Advocates of the program claimed that LSP lawyers were influential in reducing police brutality, improving police response time, and securing the actual filing of police reports. Legal services lawyers, though representing cases against Police Departments, often worked in concert with local police officers; these relationships were credited with reducing the likelihood of riots by using the judicial system to solve disputes peacefully.

Conceptually, the availability of legal aid would serve as a deterrent for unfair or unjust treatment by police authorities (i.e., police brutality or not taking reports). ${ }^{12}$ If police services were underutilized by the poor due to social and political structure or resources, LSPs would attempt to correct the market inefficiency. The examination of the victimization reports and reported crime records reveals a distinct difference between the actual and observed crime rate.

\footnotetext{
${ }^{12}$ During a 1969 Senate hearing, advocates of LSP boast on the effectiveness of legal service lawyers to intervene in riots, decrease police brutality, reduce illegal police conduct, and increase the relationship between the police and the poor community.
} 
Boggess and Bound (1999) summarized the differences between Victimization Reports and the Uniform Crime Report and surmised that reporting plays a large role in the discrepancy. According to Boggess and Bound, the large difference reflects reporting behavior of victims and witnesses as well as reporting behavior of the police. ${ }^{13}$ There are several reasons why this difference between actual and reported crime occurs. First, the pecuniary gains from reporting are likely small if the possibility of recovery is near zero. Also, the victim or observer of a crime is not likely to report if the criminal is of close relation or if retaliation is possible. Additionally, political pressure to keep crime rates down, the social economic status of victims, conviction rates, and various other reasons cause crime to go unreported. $^{14}$ If some criminal offenses are under-reported due to lack of institutional responsibility or the victims perception of lack of institutional responsibility, legal services could work to increase the number of crimes reported and the number offenses cleared by arrest. ${ }^{15}$

According to the mechanisms outlined above, the introduction of the LSP has two possible implications within a Becker type crime model. For potential criminals (supply-side), the LSP increases the quality of criminals and as a result, decreases the marginal cost of committing a crime. Consequently, this will decrease the number of crimes cleared by arrest, increase the number of crimes committed, and increase the number of crimes reported. For non-criminals (demand for crime prevention), the LSP could improve police-community relationships which increases the reporting of crime. Better policing and more

\footnotetext{
${ }^{13}$ Myers (1980) finds that the actual crime rates between 1970 and 1974 were 1.5 to 3 times larger than reports.

${ }^{14}$ Couzens and Sieidman (1974) discuss how the production of crime rates depends on the victim perspective, the police perspective, and also political pressure. Unobserved differences in any of these three areas can cause crime to be drastically under-reported across cities and vary over time. Also see Black (1970).

${ }^{15}$ Legal services lawyers have been seen as improving relationships between the community and the police. Many encounters of how the LSP have influenced behavior of local institutions are documented in congress subcommittee meetings between 1965 to 1974.
} 
reporting would also lead to an increase in arrests which serves as a deterrent for committing future crimes.

Combining the two offsetting effects, the prediction that follows is that LSPs could increase or decrease crime after legal services grants were received. Furthermore, both of these changes in crime would result in an increase in reported crime. However, what is important from a social capital perspective is whether actual crime increased or decreased due to the establishment of LSPs. My analysis uses property values to shed light on this.

\section{Data On Legal Service Grants and Crime}

Data on the recipients of federal legal services grants funded by the OEO were compiled from the National Archives Community Action Program (NACAP) files. NACAP provides information on the city, county, and state for which the funds were received and the targeted communities. Also, provided is the date the grant was issued, the amount of the grant, and a brief description for the intended purpose of the grant. I use this information to match legal services grants to city level observations on crime and I use the date of the first grant to identify when the legal services program started. ${ }^{16}$

Data on crime comes from the Uniform Crime Reporting: Offenses Known and Clearance by Arrest (UCR). The data on crime includes monthly information on the number of unfounded offenses, actual offenses, offenses cleared by arrest, and offenses cleared involving individuals under the age of 18 . The following offenses of interest are recorded in this database: murder and manslaughter, rape, robbery, assault, burglary, larceny, and motor vehicle thefts. Also recorded is the number of offenses cleared by arrest for each of these criminal offenses.

\footnotetext{
${ }^{16}$ NACAP files do not provide information for grants received in 1969. Data from Federal Outlays are used to supplement CAP data to provide grants in 1969.
} 
City characteristics in this analysis are taken from the 1960, 1970, 1980, and 1990 Census City and County Books. The city level demographic information is constructed by linearly interpolating between the 1960, 1970, 1980, and 1990 census. To calculate the proportion of the population that are males between the ages of 15 to 24 and 25 to 39 for each city, I interpolated the 1960 census county age profile to 1968 and used annual county age profiles from the Surveillance, Epidemiology, and End Results (SEER) from 1968-1985.

The analysis consists of city level observations with crime statistics and census demographic information from 1960 to 1985 for 606 cities. All cities in this sample have a population of over 25,000 residents in every year. Table 1 reports summary statistics for these cities from the 1960 census. The average population in the sample is 98,515 residents with the median income of $\$ 6,004$ dollars (\$48,019 in 2014 dollars). ${ }^{17}$ The final sample contains 208 cities that received legal services grants (treatment group) and 398 non grant cities (comparison group). Cities that received legal services grants have a larger proportion of residents who are non-white and smaller proportion of residents with more than 12 years of schooling which is reflected with lower median incomes. However, cities that received grants are similar to unfunded cities with regard to the proportion of residents who are men and between the ages of 15 to 24 and 25 to 39, a key determinant of crime (Blumstein and Rosenfeld, 2008).

\section{Event-Study Methodology}

The empirical strategy will take advantage of the variation in the location of LSPs. Although there are key cross-sectional differences between funded and unfunded cities, the identification strategy is dependent on how crime evolves before the establishment of the legal services program. Table 2 reports summary

\footnotetext{
${ }^{17}$ LSPs were located in larger cities, however, 103 of the 208 cities that received LSP grants had a population less than 100,000 residents in 1960 and 45 cities had a population less than 50,000.

Every city with a population greater than 500,000 residents in 1960 received a legal service grant.
} 
statistics for the log of criminal offenses available in the UCR between 1960 and 1964. ${ }^{18}$ According to the table, cities that received legal services grants have much higher average crime rates before 1965. This is not surprising as demographic characteristics from table 1 are known predictors of crime. Important for my research design, however, is that crime evolved similarly in treated and untreated cities prior to 1965 . This is consistent with changes in the percentage of the population in high crime age groups evolving similarly over time in treated and untreated places. My analysis will account for the crosssectional differences by using city fixed effects to capture differences in cities that are unobservable but are constant over time. Untreated cities in this analysis will help estimate how crime is evolving over time and provide a comparison group for how crime is expected to evolve after treatment. The untreated cities in this sample provides a plausible comparison group if demographic characteristic as well as city and year fixed effects capture the difference in how crime evolves in treated cities versus untreated cities before the establishment of legal services programs. A test of this assumption is embedded within the difference-indifference approached used in this analysis. If crime evolves similarly in treated and untreated cities before the establishment legal services program, my analysis will capture any trend break in crime due to the introduction of legal services.

The empirical strategy will also take advantage of the variation in the timing of the establishment of LSPs. The key identifying assumption is that the timing of the establishment of LSPs is uncorrelated with other determinants of changes in crime. The first test of this assumption is a regression of 1960 demographic characteristics that are determinants of crime on the year LSPs was established. The LSP was also supposed to be affiliated with university law

\footnotetext{
${ }^{18}$ Summary statistics are the average over 1960 to 1964 of offenses reported.
} 
programs; so ex ante, one would predict that legal services would be in cities that have law schools.

Table 3 reports weighted and unweighted estimates from ordinary least squares (OLS) regressions for the year grants were received. I use an indicator variable equal to one if a city is located in a county that has a law school and another indicator variable for if the county has a medical school. The medical school indicator captures the effect of a university versus a stand-alone law school. This can distinguish whether timing of grants are affiliated with law schools or large universities. Column 1 reports estimates from an unweighted OLS regression and column 2 reports from a weighted OLS regression (weighted by 1960 county population). ${ }^{19}$ In both columns, having a medical school or law school is associated with receiving legal services earlier. However, having a medical school in the county is not statistically significant. Law schools are weakly statistically significant in column 2 . According to table 3 , demographic characteristics fail to predict when a city first received a grant.

A second test of the identifying assumption is to compare the timing of the LSP with the pre-program reported crime rates and pre-program growth in reported crime. Figure 1 plots the changes in log of total crime from 1960 to 1964 and the reported crime in 1964 against the year of the LSP establishment. Both figures show that the timing of the LSP is uncorrelated with reported crime or changes in reported crime in the pre-period. ${ }^{20}$ These two tests provide statistical evidence that the variation in the timing of establishing LSPs were not determined by pre-period crime rates or predictors of crime.

\footnotetext{
${ }^{19}$ Weights are used to give more weight to cities that contribute more the population descriptive statistics used in the regression analysis.

${ }^{20}$ The slope in panel A is $-0.011(0.0073)$ and panel B -0.0249 (.02082). The slope for panel A \& $\mathrm{B}$ are from univariate regressions of the crime on the year LSPs were established.
} 
Legal services programs were rolled out over an 11 year interval. ${ }^{21}$ I use the variation in the timing and location of funding within an event-study framework to test for causality. The event study framework lends itself well for testing the effects of an outcome before and after exposure to the treatment and provides another falsification test for how crime is evolving before treatment. ${ }^{22}$ The pre-treatment effects test whether changes in the outcomes occur before the implementation of treatment. I estimate the effects of federally funded legal services using the following linear regression:

$$
\begin{aligned}
& Y_{i, t}=\gamma_{i}+\alpha_{t, s(i)}+\sum_{\tau=1}^{q} \pi_{-\tau} D_{i} 1\left(t-T^{*}=-\tau\right)+\sum_{\tau=1}^{p} \delta_{\tau} D_{i} 1\left(t-T^{*}=\right. \\
& \tau)+X_{i, t}^{\prime} \beta+\varepsilon_{i, t}
\end{aligned}
$$

where $Y_{i, t}$ is the annual $\log$ number of offenses per 100,000 residents in city $i$ in year $t(t=1960,1961, \ldots 1985) ; \gamma_{i}$ is a set of city effects which control for unobservable city characteristics that are time invariant; $\alpha_{t}$ is either a set of year effects or state-by-year effects $\left(\alpha_{s(i), t}\right)$. Year effects will absorb policies that will impact crime nationally such as the 1972 Supreme Court case ruling capital punishment cruel and unusual. State-by-year effects captures time-varying state level changes such as the business cycle or policy changes (e.g. punishment, enforcement) which may influence the supply of criminal activity.

The row vector $X_{i, t}$, consists of covariates from the 1960, 1970, 1980, and 1990 census, which I have linearly interpolated between census years. ${ }^{23}$ The covariates are the proportion of the non-white population, the proportion of males between 15 to 24 years of age, the proportion of males between 25 to 39 years of

\footnotetext{
${ }^{21}$ Legal Services operated under the OEO until October of 1974 when it became the Legal Service Corporation.

${ }^{22}$ For other papers using event study framework see Bailey (2013), Jacobson et al (1993), Kline (2010), and McCrary (2007).

${ }^{23}$ Census information is gathered in the County and City Data Book and is publicly available at the ICPSR website.
} 
age, percentage of population with more than 12 years of education, and family median income. Because using the treatment may actually have an effect on the controls, I estimate the regression with and without the covariates from the census for robustness of the specification. $D_{i}$ is an indicator variable equal to one if the city ever received federally funded legal services. $1\left(t-T^{*}=-\tau\right)$ is an indicator variable equal to one if the observation year is $-\tau$ years from the date that the legal services grant is received or $1\left(t-T^{*}=\tau\right)$ is equal to one if the observation year is $\tau$ years after the date legal services were first available. $1\left(t-T^{*}=0\right)$ is omitted due to collinearity where $T^{*}$ is the funding year for the legal services grant; $q$ refers to the number of lags or years before legal services are funded, and $p$ is the lead or years after legal services are funded. To ensure the coefficients are well estimated, event time for $\tau>10$ and $\tau<-5$ are grouped into endpoints, $q$ $=6$ and $p=11$. The endpoint coefficients are not estimated using a balanced sample of cities and will also give unequal weight to cities that receive federal grants very early or late in the sample. These endpoints, therefore, are omitted from the presentation of results.

In the sample, cities receive legal services grants between 1965 and 1975 . A balanced event panel using UCR data on criminal offenses from 1960 to 1985 will focus on five years before and ten years after federally funded legal services are received. The coefficients of interest are $\pi_{-\tau}$, which are pre-treatment effects, and post-treatment effects $\delta_{\tau}$. These estimates describe the dynamics of reported crime in funded cities before and after legal services grants are received. If the econometric model captures the pre-legal services evolution of the dependent variable, the pre-treatment effects should be indistinguishable from zero. The treatment effects, $\delta_{\tau}$, is the average change in the difference in criminal offenses $\tau$ years after the city received the grant. 


\section{Results}

\section{A. Using the Timing of First Grants to Identify Impact}

Using the estimates from equation 1, I plot pre-treatment effects and posttreatment effects from a balanced panel. Figure 2 plots the estimates from three different specifications of equation 1 . Model 1 is plotted in the solid line with no markers. It contains only city and year effects. Model 2 is plotted with a solid line and circle markers and includes city and state by year effects. Model 3 also includes city and state-by-year effects with additional city characteristics interpolated from 1960 to 1985 using the 1960, 1970, 1980, and 1990 census data and is plotted with square markers. I present 95-percent confidence intervals for model 2 and 3 by dashed lines. The confidence intervals are constructed from heteroskedasticity robust standard errors clustered by city. The sample consists of cities with population greater than 25,000 residents in every year but excludes New York City, Los Angeles, and Chicago. Presented are estimates where the natural $\log$ of crime is the dependent variable $Y_{i, t}$ for equation 1. All regressions are estimated using the 1985 population as weights to correct heteroskedasticy related to city size in the error term. ${ }^{24}$

Figure 2 plots pre-treatment and post-treatment effects for federal legal services grants on log of total criminal offenses reported per 100,000 residents. Total crime is an unweighted aggregate of property crime and violent crime. Property crime includes burglary, larceny, and motor vehicle theft, whereas violent crime aggregates include murder, manslaughter, rape, assault, and robbery. According to all three models, the point estimates for $\pi_{-\tau}$ are near zero or slightly less than zero but statistically insignificant. After the first year of operations, changes in offenses reported are positive and statistically significant.

\footnotetext{
${ }^{24}$ Weighted least squares is used to make error term homoscedastic. New York, Chicago, and Los Angeles are removed to avoid giving these cities enormous weight in addition to having cities to compare them with.
} 
The log of actual offenses reported increases drastically over the next three years and is statistically significant. Using model 3 estimates, total crime per 100,000 residents increases 7 percent three years after treatment. Three and four years after treatment, total crime reported begins to decrease and eventually becomes indistinguishable from zero. The results are consistent with buildup of services within a community. After the grant is received, neighborhood legal services will have to hire staff, build community support and rapport, while also accumulating exposure.

Estimates in figure 3 are produced using weighted least squares and exclude New York, Chicago, and Los Angeles. These cities are excluded to avoid giving them enormous weight. More importantly, these cities lack a proper comparison within the treated or control samples, which is important because identification is dependent on both timing and location. ${ }^{25}$ Population weights are used in my analysis to gain efficiency when error term has heteroskedasticity related to city size. However, weighted least squares (WLS) often lead to estimates that are less efficient than ordinary least squares (OLS) estimates (Haider, Solon, and Wooldridge, 2013). In my analysis, weighted least square produces estimates of the pre-treatment effects that are smaller in absolute value and have smaller $t$ ratios than OLS estimates. Also post-treatment effects for WLS regressions are larger than OLS estimates and have larger t-ratios. This is consistent with WLS procedure capturing the pre-period trend in crime. ${ }^{26}$

\section{B. Interpretation of the Impact of Federally Funded Legal Services}

The availability of legal services is associated with a large increase in crime as predicted under the context of Becker's Crime Model. The hump shape response indicates that there is an increase in crime followed by a decrease in

\footnotetext{
${ }^{25}$ Chicago, Los Angeles, and New York receive legal service grants in 1966.

${ }^{26}$ Estimates including New York, Chicago, and Los Angeles as well as OLS regression are available upon request.
} 
crime after legal services became available. However, the hump shape response does not distinguish between changes in actual crime or the reporting of crime. On one hand, this result is consistent with LSPs increasing the demand for police service and reducing the demand for crime. Advocates of the LSP boasted about its effectiveness in reducing police brutality, minimizing or stopping riots, increasing victim response time, and ensuring filing of police reports. Improvements in these areas should enhance the relationship between the poor and police. Ensuring police filed reports alone will increase the reported crime rate without changes in criminal behavior. By protecting the poor's legal rights to adequate law enforcement protection and services, legal services could increase the likelihood that a crime is reported and also increase the likelihood that the report would be investigated. In general, these effects will not only lead to more reporting but also increase the probability of arrest, given a criminal offense occurred.

While the intertemporal response of reported crime provides evidence of changes in reporting behavior, I cannot dismiss the possibility of changes in criminal behavior. In part, the hump shape response is also consistent with an increase in actual crime followed by a decrease in crime. According to opponents, LSP lawyers decreased the probability of arrest and conviction. The combination of these effects could embolden criminals and result in more crimes being committed. Although not articulated by opponents, the decrease in crime could be a result of increased police effort to clear offenses by arrest. Despite the conflicting view points, it is clear that the establishment of legal services increased reported crime in treated cities.

\section{Event-study results for Arrest and Number of Police Officers}


Figure 3 plots pre-treatment and post-treatment effects for log of arrest per 100,000 residents. ${ }^{27}$ I have valid arrest data from 1963 to 1985; therefore, I only have one year for the pre-treatment. As with reported crime, pre-treatment effects are zero and post-treatment effects are positive and statistically significant. Worth noting is the magnitude of arrest compared to reported crimes. In figure 2 total criminal offenses reported increased by 7 percent after three years and then by the fifth year after treatment, the effects were not distinguishable from zero. Here, total arrests increased by 16 percent after three years and the post-treatment effects remain high for the next couple of years before declining to zero. In this case, the response to legal services and the increase in reported crime resulted in a dramatic increase in arrests in treated cities. The percentage increase in arrests after legal services become available is double the percentage increase in crimes reported.

As mentioned earlier, legal services often filed laws suits which requested additional police officers and a more diverse police force. Figure 4 plots pretreatment and post-treatment effects for the log of sworn police officers per 100,000 residents. Before legal services are available the pre-treatment effects are zero. After legal services become available the log of sworn police officers increases over the next 10 years relative to untreated cities. The post-treatment effects, clearly shows a large immediate increase in the log of sworn police officers after legal services are established. ${ }^{28}$ An increase of 2.2 percent in the first year is the largest increase over the next ten years. The increase in sworn police officers in the first year is an average increase of 8 additional police officers in treated cities. Using estimates of police elasticities from research on

\footnotetext{
${ }^{27}$ Mas (2006) also used clearance rates as a proxy for police performance. Here, by protecting the rights of the poor, should also be reflected in more effort and energy to doing better police work. Using clearance rates serves as a proxy.

${ }^{28}$ Police employment data from the Annual Survey of Government provide results similar to the estimates displayed in figure 4.
} 
crime and police from Levitt (1997, 2002) and McCrary (2002, 2013), this implies that violent crime would be expected to be reduced by 6 to 14 crimes per 100,000 residents because of additional police officers. The reduction in property crime would be between 25 and 94 crimes per 100,000 residents.

\section{Event-study results by UCR crime category}

Figure 5 plots pre-treatment effects and post-treatment effects from model 3 for the effect of legal services on property and violent crimes reported. Results for property crime show that five years before federal legal services grants, funded cities are indistinguishable from unfunded cities. According to Model 3, the point estimates for $\pi_{-\tau}$ are zero or slightly less than zero but statistically insignificant. Three years after federally funded legal services are implemented, the number of crimes reported increased on average by 93 property crimes per 100,000. Three years after a city received a legal services grant, property crimes continued to grow at a steady pace. Similar to property crimes, the pre-treatment effects for reported violent crimes are not statistically significant. After the first year of operations, changes in violent offenses reported are positive and increased over the next 3 years.

Figure 6 plots pre-treatment and post-treatment effects for log of criminal offenses reported per 100,000 residents for sub-categories of property and violent crimes. Panel A displays the result for the log of murder per 100,000 residents. The estimates show a steady increase in the log of murders reported before and after treatment but the estimates never becomes statistically significant nor does it display hump-shape response. After legal services begin, the log of rapes per 100,000 residents and the $\log$ of robberies per 100,000 residents reported increase and are statistically significantly. Panel C and D plot treatment effects for assault, burglary, larceny, and motor vehicle theft. Pre-treatment effects for larceny are positive and statistically different from zero. Post-treatment effects are positive 
and statistically different from zero after a few years. Motor vehicle theft and burglaries post-treatments are positive, statistically different from zero, and follow the hump shape response of total crimes.

Property and violent crimes, as well as total crime, responded in a similar fashion to the establishment of legal services. The post-treatment effects of murder and manslaughter are not statistically significant which support the notion that legal services increased reported crime and not actual crime. Murder and manslaughter are reported fairly accurately and proxies for changes in actual crime. The zero post-treatment effects for murder and manslaughter show that LSPs were unlikely to increase actual crime. Also, crimes that are typically under-reported, such as rape, display the largest increase. This is consistent with an increase in reporting in places where legal services are established.

The notion that crime is decreasing while reporting is increasing is not unique in the crime literature. ${ }^{29}$ Boggess and Bound (1997) showed that reported crime increased in the UCR in the 1980's while crime decreased according to the National Crime Survey. ${ }^{30}$ They concluded that overall criminal activity decreased by virtue of the fact that the murder rate declined over the sample period, while reporting over the sample period increased. Consistent with their story, my results indicate that the impact of LSPs on murder and manslaughter are statistically insignificant although the post-treatment estimates are positive.

However, other criminal categories that are reported somewhat accurately indicate that crime may actually be increasing due to legal services. Two categories that are likely to be reported somewhat accurately are robberies and

\footnotetext{
${ }^{29}$ Levitt (1998) makes a similar argument about the effect of police on the reporting of crime. Levitt argues that an increase in police officers increases the likelihood that a crime is reported and reduces that amount of actual crime that occurs.

${ }^{30}$ National Crime Survey was implemented in 1972 to collect data on victimization. The data is administered by the Bureau of Justice Statistics and available at the ICPSR. The NCS provides information about crimes reported and not reported to the police as well as provides information about the victim and the offender. The increase in reporting overtime is also substantiated by Biderman and Lynch (1991).
} 
motor vehicle theft (Bogges and Bound, 1997; Levitt, 1998). According to figure 6, the post-treatment effects are positive and statistically significant. If LSPs are improving reporting of crimes, it is reasonable to assume that murders and motor vehicle theft would be unaffected. However, I find large effects for motor vehicle theft and a positive effect on murder. It is quite possible that legal services are associated with increases in actual crime or are associated with events that increased crime.

\section{Discussion}

\section{A. Legal Services and Property Values}

Evidence thus far indicates that the establishment of legal services programs increase reported crime. These estimates imply that LSPs are associated with an increase in reported crime of roughly 7 percent. Legal services are also associated with an increase in arrest and the number of police officers in treated cities. All together these results are consistent with legal services reducing crime and increasing social capital by requiring citizens and public institutions to become more responsible for community development. However, they may also reflect an increase in crimes committed.

One attempt to distinguish between changes in actual crime versus reported crime is to examine changes in the value of homes. Reducing crime will make communities safer and consequently influence property values in treated cities. Conversely, an increase in crime would reduce them. This is consistent with Lynch and Rasmussen (2010) which showed that housing prices are highly discounted in high crime areas. Also an increase in criminal activities or an increase in the number of potential criminals can negatively influence the value of homes (Coldwell, Dehring, and Lash; 2000; Linden and Rockoff; 2008). The race riots of the 1960s have been linked to lower property values in 1980 by Collins and Margo (2007). Lastly, Pope and Pope (2010) showed that there is a negative 
relationship between crime and property values. They conclude that cities displaying the largest decrease in crime in the 1990s also had the largest increase in property values by the year 2000 . If legal services decrease crime, the increase in social capital should be reflected in the property value of homes. To test this hypothesis I will use the median property value from 1960, 1970, and 1980 census as the dependent variable similar to Collins and Margo.

There is caution required in using the median property value as a measure of welfare. In part, is likely that users of legal services were not home owners and property value will not capture changes in the welfare of the poor. Additionally, changes in the property value in high crime areas may not impact the value of property in low crime areas or the median home owner. However, policing and criminal activity is a city level statistic and can have spillover effects within a city. Policing high crime areas and minimizing the opportunity for crime to spread outside of high crime areas could be reflected in the median property value of all home owners. Therefore, using median property value is a modest attempt to estimate the causal effect of LSPs on the welfare of the poor and the community as a whole.

To analyze the impact of LSPs on property values, I estimate the following difference-in-difference regression:

$$
Y_{i, t}=\gamma_{i}+\alpha_{t}+\delta L S P_{i, t}+X_{i, t}^{\prime} \beta+\varepsilon_{i, t}
$$

The dependent variable is the log of the median residential property value for all home owners in city $i$ in year $t$ from 1960, 1970, and 1980 Decennial Census. $L S P$ is equal to $D_{i} 1\left(t-T^{*}>0\right)$ which is an indicator variable that is equal to one if a legal services project is operating in city $i$ before census year $t$. The row vector $X_{i, t}$, consists of covariates from the 1960,1970 , and the 1980 census. The covariates are the natural log of the following: the proportion of the non-white 
population, percentage of population with more than 12 years of education, and the population per square mile. Also included is an indicator variable equal to one if a riot has occurred in city $i$ before census year $t$. The riot data comes courtesy of Collins and Margo (2007). This data consists of detailed information of riots occurring between 1964 and 1971.

Table 4 displays the results from equation 2 where the dependent variable is the log of the median residential property value for all home owners. According to column 1, property values are two percent higher in cities that receive legal services. Column 2 adds additional covariates: the log of median income and log of the percentage of the population with 12 or more years of education. Estimates in column 2 further support that the impact of LSPs on property value is positive and the results are larger and statistically significant. According to column 3, cities that receive legal services earlier are associated with higher property values in 1970 and 1980 relative to cities that did not receive legal services or receive legal services later. Higher property values are consistent with LSPs increasing social capital and making these communities safer and better off. The increase in social capital through changes in reporting, according to advocates, was driven by lawyers improving the relationship between the poor and institutions that interacted with the poor.

To aggregate the effect of LSPs on property values, I use the same procedure used in Collins and Margo. Using the estimated effects in column 2, I predict the log-value of median property values in 1980 for each city. Using these predicted values, I calculate a counterfactual for property values in treated cities by subtracting the estimated value-added due to legal services. Using the number of owner occupied housing in each city as weights, I calculate the weighted average of property values in 1980 across cities to construct an average counterfactual value of homes. The weighted average of property values in the non-LSP counterfactual is $\$ 16,273$. The weighted average of the actual property 
in 1980 is $\$ 17,370$. The difference between the actual and counterfactual property values implies an additional $\$ 1,097$ in property value due to the presence of LSPs. The average number of owner occupied housing in 1980 across cities is 22,200. Using this number, legal services is associated with a 24 million dollar increase in property values by 1980 .

\section{B. Using Rioting to Distinguish Changes in Reported Crime}

It is reasonable to be concerned that the significant increase in reported crime after exposure to federally funded legal services is a direct consequence of riots that occur during this time period. ${ }^{31}$ The inclusion of year fixed effects will capture national events that increase crime across cities. However, all riots are not triggered by national events. Therefore, year fixed effects and state by year fixed effects will not capture changes in local sentiments that may result in riots. If the increase in reported crime is purely a consequence of rioting, then legal services were either established in locations where rioting would occur or in places where rioting was the most intense or severe. Although riots are considered spontaneous events (Collins \& Margo 2007), it is likely that LSPs are established in places where the tension between institutions and the poor/minorities is high. As mentioned before, the program was considered an anti-rioting initiative by advocates and thus selection on the likelihood of riots is plausible but difficult to test.

To examine these concerns, I use riot data from Collins and Margo (2007). Included this data is a riot severity index which compares riots across cities in the sample. I use the riot intensity index to test how rioting effect my estimates. Table 5 displays estimates for the $\log$ of total crime per 100,000 residents. Column 1 includes estimates of model 3 from figure 3 . Column 2 displays

\footnotetext{
${ }^{31}$ According to data from Collins and Margo (2007), 409 riots are recorded in 193 cities in the sample. Event-studies estimates show that riots are associated with higher level of crime after the first riot in a city occurs. These estimates are not presented but are available upon request.
} 
estimates from model 3 including a variable for riot intensity in city $j$ in year $t$. Estimating the effect of legal services on total criminal offenses reported accounting for rioting does not change the pre- and post-treatment effects. The coefficient on rioting is positive and statistically significant but small. There are various explanations why this occurs. One reason is that many of the riots in Collin and Margo's data are relatively small. Also, more intense riots may reflect changes in national sentiment and are captured by year fixed effects. Lastly, changes in crime could be a post-riot effect related to changes in demographics and economic activity due to rioting.

\section{Other War on Poverty Grants}

Another reasonable concern is that any impact of the LSP is just a reflection of other programs introduced in President Johnson's War on Poverty. The LSP operated within Community Action Agencies until 1969. The link between legal services and community action agencies are not linear in the sense that there are locations with legal services and without community action agencies (and vice versa). Table 6 reports pre-treatment and post-treatment effects for the Office of Economic Opportunity grants on log of total criminal offenses reported per 100,000 residents. In column 1, the event is the timing of the first Head-Start grant, column 2, uses Community Action Agency grants, and column 3 uses Legal Services grants. Head-Start provides a placebo test since this program was not linked to community action agencies. While the Community Action Agency is a test of the litany of programs housed as Community Action Programs. According to table 6, pre-treatment and post-treatment effects in columns 1 and 2 are not statistically significant. If changes in reported crime were due to the influx of resources devoted toward fighting poverty and not legal services, column 2 would show a significant decrease or increase in reported crime. 
However, reported crime only changes when the event is the establishment of the legal service program.

\section{Conclusion}

In 1960 many legislative acts and federal programs were implemented to increase the quality of life of the poor, reduce poverty, and improve urban communities. This declaration of reform is reflected in the War on Poverty initiated in 1964 by President Lyndon B. Johnson. However, introducing social programs such as Head Start and Job Corps was deemed too small according to President Johnson. At Howard University's Commencement in 1965 he stated, "It is not enough just to open the gates of opportunity. All our citizens must have the ability to walk through those gates." The LSP was established to equip the poor with the tools to do just this. Fifty years later however, research has failed to evaluate the impact of the LSP, partially because of the difficulty with quantifying its effects.

Federally funded legal services attorneys are historically credited with advocating on behalf of the poor to stop police brutality, increase response times to victims, ensure that reports are filed and investigated, and change policing policies. However, individuals that opposed the program identified it as an antigovernment program that emboldened criminals. My results are consistent with its proponents rather than its opponents, showing the establishment of legal services as increasing the demand for law enforcement services; also, that the legal services program is associated with places having higher property values. These results suggest that the LSP was impactful and this would have had primary importance for individuals who could not articulate grievances before the program began. Crime is one of many areas in which this program could have influenced how public institutions interacted with the poor. Other implicitly affected areas could include: welfare recipients, divorce, evictions, as well as changes in debt 
repayment which can greatly change an individual's and a community's economic outlook. This study as a whole indicates that the LSPs had far reaching implication on the poor and urban communities. Providing impoverished communities advocates to articulate grievance can increase demand for underutilized goods as well as improve institutions that may be inefficiently servicing the disadvantaged. 


\section{REFERENCES}

Almond, Douglas, Hilary W. Hoynes and Diane Whitmore Schanzenbach. (2011). "Inside the War on Poverty: The Impact of Food Stamps on Birth Outcomes." The Review of Economics and Statistics, 93(2)

Almond, Douglas, Kenneth Chay and Michael Greenstone. "Civil Rights, the War on Poverty, and Black-White Convergence in Infant Mortality in the Rural South and Mississippi." American Economic Review. (forthcoming)

Bailey, Martha J. (2013) "Reexamining the Impact of U.S. Family Planning Programs on Fertility: Evidence from the War on Poverty and The Early Years of Title X." American Economic Journal - Applied Economics, 4(2)

Bailey, Martha J. and Andrew Goodman-Bacon (2013) "The War on Poverty's Experiment in Public Medicine: The Impact of Community Health Centers on the Mortality of Older Americans" Working Papers

Baldwin, Fred D. (1973) "Evaluating the OEO Legal Service Program." Policy Sciences, 4(3)

Barden, J.C. "Disgust Spawned Suit by 12 Wives." (1976, Dec. 12) New York Times, p. 73

Becker, Gary S. (1967) "Crime and Punishment: An Economic Approach.” Journal of Political Economy, (76)2

Biderman, Albert and James P. Lynch (1991) Understanding Crime Incidence Statistics: Why the UCR diverges from the NCVS. Springer-Verlag: New York.

Black, Dan. (1970) "Production of Crime Rates." American Sociological Review, 35(4).

Blumstein, Alfred and Richard Rosenfeld. (2008) "Factors Contributing to U.S. Crime Trends." Understanding Crime Trends: Workshop Report, The National Academies: Washington, DC

Boggess, Scott and John Bound. 1997, "Did Criminal Activity Increase During the 1980s: Comparisons Across Data Sources," Social Science Quarterly, 18:725-739

Cahn, Edgar and Jean Cahn. (1964) "The War on Poverty: A Civilian Perspective." Yale Law Journal, 73(8)

Carter, Gregg Lee. (1986) "The 1960s Black Riots Revisited: City Level Explanations of Their Severity." Sociological Inquiry, 56(2)

Chalfin, Aaron and Justin McCrary. (2013) "The Effect of Police on Crime: New Evidence from U.S. Cities, 1960-2010." Working Paper

Champagne, Anthony S., and Stuart Nagel. Legal Service Agencies, 1970. ICPSR07369v1. [Computer file] Ann Arbor, MI: Inter-university Consortium for Political and Social Research [distributor], 1996. doi:10.3886/ICPSR07369.v1

Champagne, Anthony. (1974) "An Evaluation of the Effectiveness of the OEO Legal Service Program." Urban Affairs Review, 9(4)

Champagne, Anthony. (1974) "The Internal Operations of OEO Legal Service Projects." Journal of Urban Law, 51 p. 649

Collins, Williams J. and Robert Margo. (2003) "Race and the Value of Owner-Occupied Housing, 1940-1990." Regional Science and Urban Economics, p. 255

--- (2007) "The Economic Aftermath of the 1960's Riots in American Cities: Evidence from Property Values.” Journal of Economic History, 67(4) 
Cullen, Julie B. and Steven Levitt. (1999) "Crime, Urban Flight, and the Consequences for Cities." The Review of Economics and Statistics, 81(2)

Couzens, Michael and David Seidman. (1974) "Getting the Crime Rate Down: Political Pressure and Crime Reporting." Law \& Society Review, 8(3)

Colwell, Peter F., Carolyn A. Dehring, and Nicholas A. Lash (2000) "The Effect of Group Homes on Neighborhood Property Values." Land Economics, 76(4)

Erlanger, Howard S. (1978) "Lawyers and Neighborhood Legal Services: Social Background and the Impetus for Reform." Law \& Society Review, 12(2)

Erlanger, Howard S. (1976) "The Social Reform Organizations and Recruitment of Professionals: Lawyers and the OEO Legal Services Program." Institute for Research on Poverty Discussion Papers, 344-76

Finman, Ted. (1971) "OEO Legal Service Programs and the Pursuit of Social Change," Wisconsin Law Review, 1001

Gillette, Michael L. (1996) Launching the War on Poverty: An Oral History, Twayne Publishers: New York.

Grimes, Ruth-Ellen and Dennis Loo. (2004) "Polls, Politics, and Crime: The "Law and Order" Issue of the 1960s." Western Criminology Review, 5(1)

Greenwood, Noel. (1968, July 7) "Poverty Lawyers to Shift Emphasis from Individual to Class Actions" Los Angeles Times, pp. WS1

Haider, Steven, Gary Solon, and Jeffrey Wooldridge (2013) "What Are We Weighting For?" Journal of Human Resources. (Forthcoming)

Haines, Michael R. and Inter-University Consortium for Political and Social Research. (2005). Historical, Demographic, Economic, and Social Data: The United States, 1790-2002 [Computer file]. ICPSR02896-v3. Ann Arbor, MI: Inter-university Consortium for Political and Social Research [distributor], 2005. doi:10.3886/ICPSR02896

Hannon, Philip J. (1969) "The Leadership Problem in the Legal Services Program." Law \& Society, 4(2)

Herbers, John. (1967, Aug 8) "Newark Jailer Says Poverty Aides Stirred Riots." New York Times, p. 24

Hoynes, Hilary and Diane Schanzenbach. (2009). "Consumption Reponses to In-Kind Transfers: Evidence from the Introduction of the Food Stamp Program." American Economic Journal: Applied Economics 1(4)

Hoynes, Hilary W., Marianne E. Page, and Ann Huff Stevens. (2006). "Poverty in America: Trends and Explanations." Journal of Economic Perspectives 20(1)

Jacobson, Louis S., Robert J. LaLonde, and Daniel G. Sullivan. (1993). "Earnings Losses of Displaced Workers." American Economic Review, 83(4)

Janowitz, Robert T. and Harry P. Stumpf. (1969) "Judges and the Poor: Bench Responses to Federally Financed Legal Services." Stanford Law Review, 21(5)

Johnson, Earl Jr. (1974) Justice and Reform, Russell Sage Foundation: New York.

Katz, Jack. (1978) "Lawyers for the Poor in Transition: Involvement, Reform, and the Turnover Problem in the Legal Service Program.” Law \& Society Review, 12(2)

Kline, Patrick. (2010) "The Impact of Juvenile Curfew Laws on Arrest of Youth and Adults." Working Papers, December 
Ladinsky, Jack. (1970) "Law, Legal Services, and Social Change: A Note on the OEO Legal Service Program.” Institute for Research on Poverty Discussion Papers, 8570

Lee, Jin Young and Gary Solon (2011) "The Fragility of Estimated Effects of Unilateral Divorce Laws on Divorce Rates," B.E. Journal of Economic Analysis and Policy (Contributions), 11(1)

Levine, Robert A. (1970). The Poor Ye Need Not Have with You: Lessons from the War on Poverty. MIT Press: Cambridge

Levitan, Sar. (1969) The Great Society's Poor Law, The Johns Hopkins Press: Baltimore.

Levitt, Steven. (1997) "Using Electoral Cycles in Police Hiring to Estimate the Effect of Police on Crime." The American Economic Review, 87(3)

--- (1998) "The Relationship Between Crime Reporting and Police: Implications for the Use of Uniform Crime Reports." Journal of Quantitative Criminology, 14(1)

--- (2002) "Using Electoral Cycles in Police Hiring to Estimate the Effect of Police on Crime: Reply." The American Economic Review, 92(4)

"Legal Aid assured of Federal Support." (1970, Jan 24) The Baltimore Afro-American, p. 20

"Legal Services: Challenging the Power." (1971, May 27) Los Angeles Sentinel, p. A8

Linden, Leigh and Jonah E. Rockoff. (2008) "Estimates of the Impact of Crime Risk on Property Values from Megan's Laws." The American Economic Review, 98(3)

Lott, John R. and John Whitley. (2003) "Measurement Error in County-Level UCR Data." Journal of Quantitative Criminology, 19(2)

Ludwig, Jens and Douglas L Miller (2007). "Does Head Start Improve Children's Life Chances? Evidence from a Regression Discontinuity Design." Quarterly Journal of Economics 122 (1): 159-208.

Lynch, Allen K. and David Rasmussen. (2004) "Measuring the impact of crime on house prices." Applied Economics, 33(15)

Maltz, Michael D. and Joseph Targonski. (2002) "A Note on Use of County-Level UCR Data." Journal of Quantitative Criminology, 18(3)

Mas, Alexandre (2006) "Pay, Reference Points, and Police Performance." Quarterly Journal of Economics, 121(3)

McCrary, Justin. (2002) "Using Electoral Cycles in Police Hiring to Estimate the Effect of Police on Crime: Comment" The American Economic Review, 92(4)

--- (2007) "The Effect of Court-Ordered Hiring Quotas on the Composition and Quality of Police." American Economic Review, 97(1)

--- (2010) "Dynamic Perspectives on Crime" Handbook of the Economics of Crime, Edward Elgar: Northhampton.

Myers, Samuel L. (1980) "Why Are Crimes Underreported? What is the Crime Rate? Does it Really Matter?" Social Science Quarterly, 61(1)

O'Reilly, Kenneth, (1988) "The FBI and the Politics of the Riots, 1964-1968." The Journal of American History. 75(1) p. 91-114.

"Pardon for Rioters?" (1968, April 13) Chicago Tribune, p. N6

Parente, S. L. and Prescott, E. C. (1999), "Monopoly Rights: A Barrier to Riches" American Economic Review. 89 
Pious, Richard M. (1971) "Policy and Public Administration: The Legal Services Program in the War on Poverty." Politics Society, p. 365

Pope, Devin and Jaren Pope. (2012) "Crime and Property Values: Evidence from the 1990s crime drop." Regional Science and Urban Economics, 42, p. 177-188

Pye, A. Kenneth. (1966) "The Role of Legal Services in the Antipoverty Program." Law and Contemporary Problems, 31(1)

"Subsidizing Violence and Subversion" (1970, Mar. 22) Chicago Tribune, p. 24

Sullivan, Lawrence A. (1971) "Law Reform and the Legal Services Crisis" California Law Review, 59(1)

Surveillance, Epidemiology, and End Results (SEER). (2009). Program Populations (1969-1988). National Cancer Institute, DCCPS, Surveillance Research Program, Cancer Statistics Branch, released November 2009. Downloaded from www.seer.cancer.gov/popdata.

Wolfers, Justin (2006) "Did Unilateral Divorce Laws Raise Divorce Rates? A

Reconciliation and New Results." American Economic Review, 96(5)

Wright, Eric W. (1967) "Competition in Legal Services under the War on Poverty." Stanford Law Review, 19(3)

U.S. Department of Justice, Federal Bureau of Investigation. Uniform Crime Reports 1960-1974. Government Printing: Washington, DC

U.S. Department of Justice, Federal Bureau of Investigation. Uniform Crime Reporting Program Data: Offenses Known and Clearance by Arrest, 1960 -1974. Compiled by the U.S. Dept. of Justice, Federal Bureau of Investigation. [Computer files] ICPSR04188-v1 - ICPSR04202-v1. Ann Arbor, MI: Inter-university Consortium for Political and Social Research [producer and distributor], 2005. doi:10.3886/ICPSR04188.v1 - doi:10.3886/ICPSR04202.v1

U.S. Department of Justice, Federal Bureau of Investigation. Uniform Crime Reporting Program Data: 1975-1997. [Computer file] ICPSR09028-v5. Ann Arbor, MI: Interuniversity Consortium for Political and Social Research [distributor], 2009. doi:10.3886/ICPSR09028.v5

U.S Senate, Subcommittee on Employment, Manpower and Poverty of the Committee on Labor and Public Welfare, Legal Services Program of the Office of Economic Opportunity, Hearing, Nov 14, 1969. Washington: Government Printing Office, 1969 


\section{APPENDIX}

Figure 1. Crime Rates before the Legal Services Program Began

A. $\Delta$ in Log of Total Crime 1960-1964

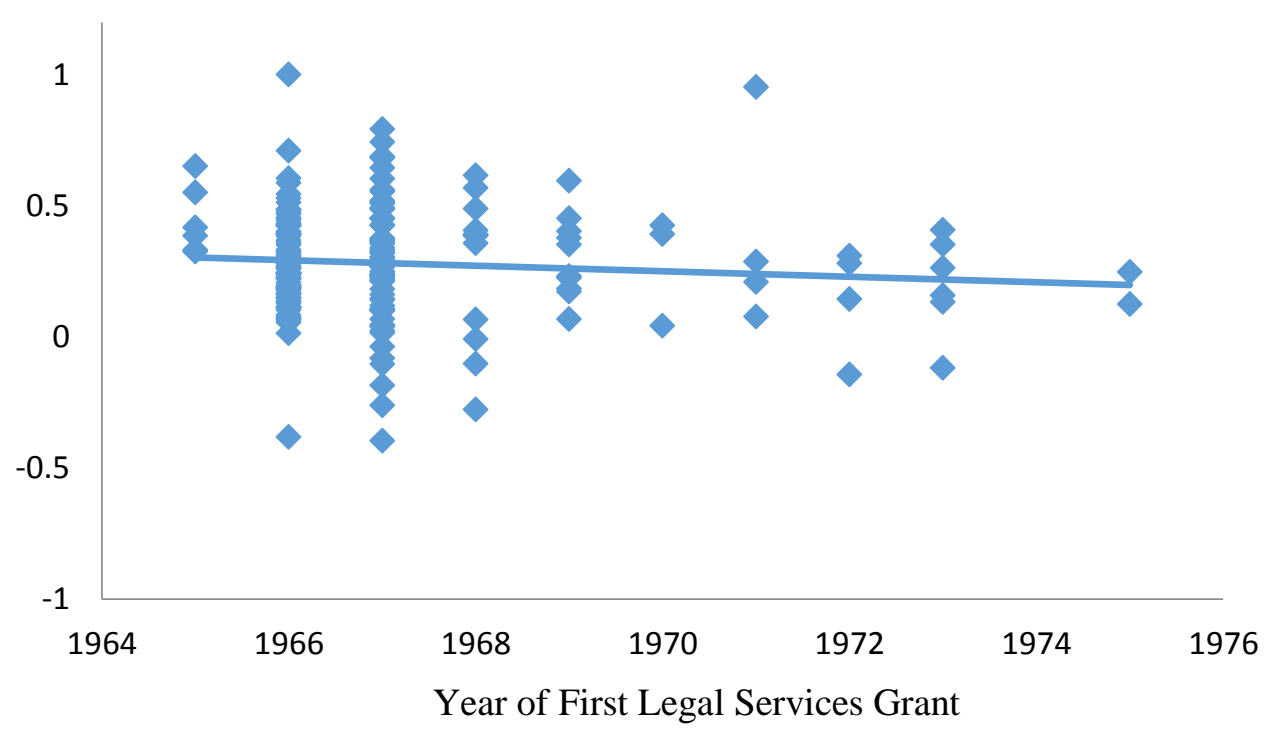

B. $\quad$ Log of Total Crime per 100,000 Residents 1964

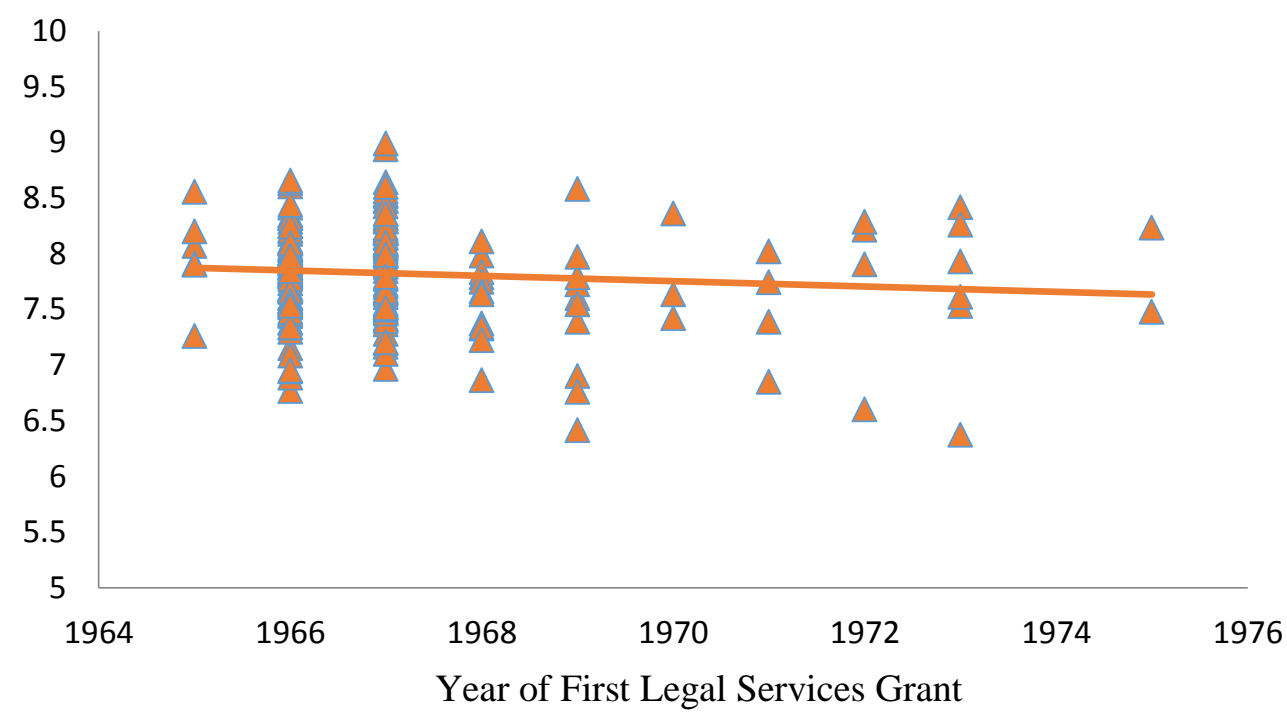

Notes: Panel A \& B: Regression coefficients and predicted values are from univariate regressions of the dependent variable crime on the year LSPs were established. The slope in panel A is -0.011 (0.0073) and panel B -0.0249 (.02082). 
Figure 2. Estimates of the Effects of LSP on Log of Total Crimes

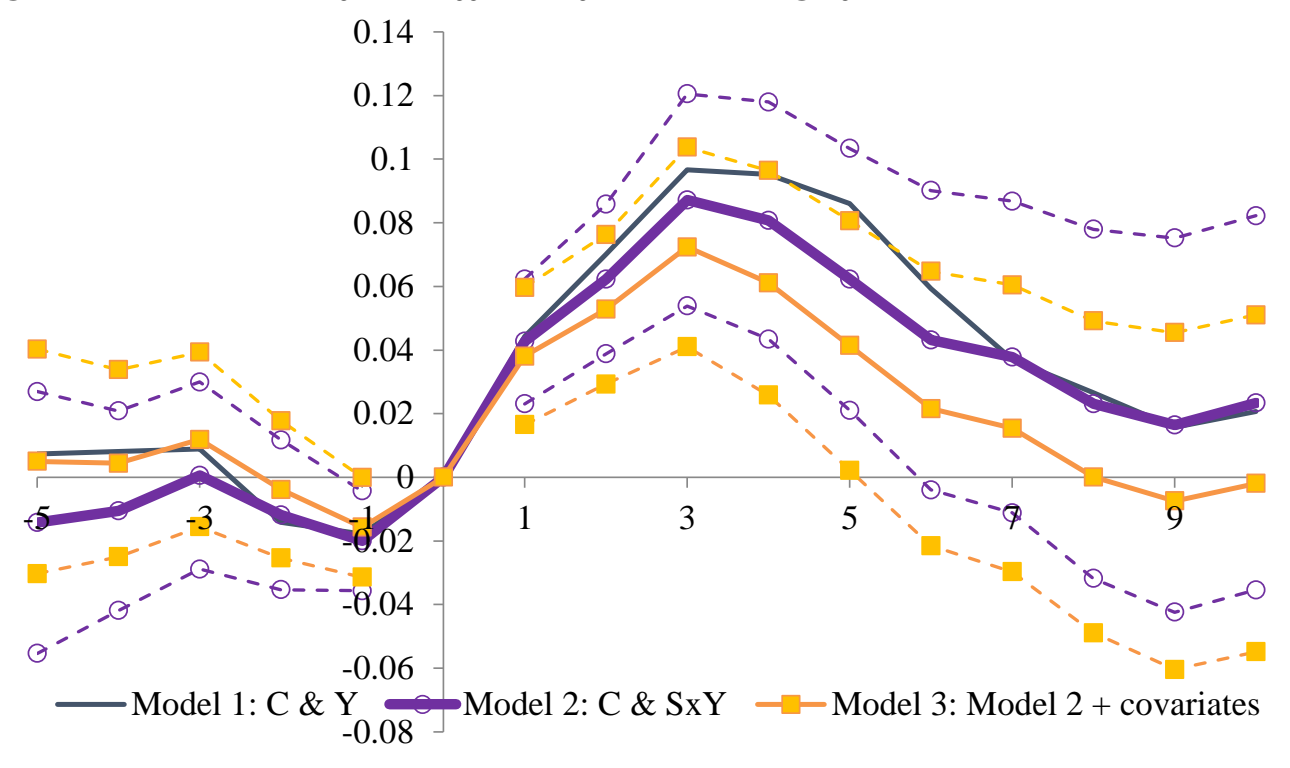

Figure 3. Estimates of the Effects of LSP on Log of Total Arrest

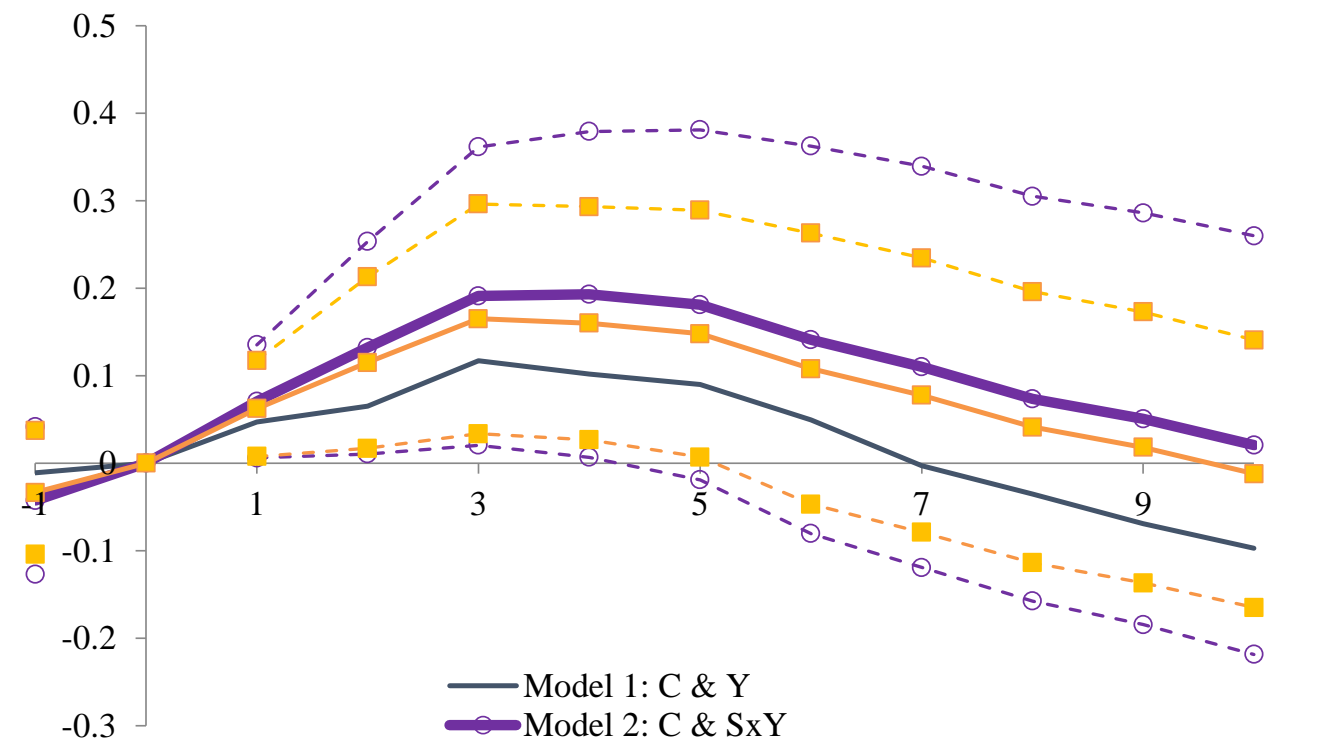

Notes: Figures 2 \& 3: Model 1 includes City, C, and year, Y, effect. Model 2 include city and state-by-year, S-Y, effects. Model 3 adds covariates from county and city data book, X, to model 2. Covariates include median household income, percentage of population under age of 5 , percentage of the population over the age of 64 , percentage of population nonwhite, and the percentage of population with 12 or more years of education, which are from the decennial census. Heteroskedasticity-robust standard errors clustered by city are presented for model $2 \& 3$. Each regression is weighted by 1985 population and excludes New York, Chicago, and Los Angeles. 
Figure 4. Estimates of the Effects of LSP on Log of Sworn Police

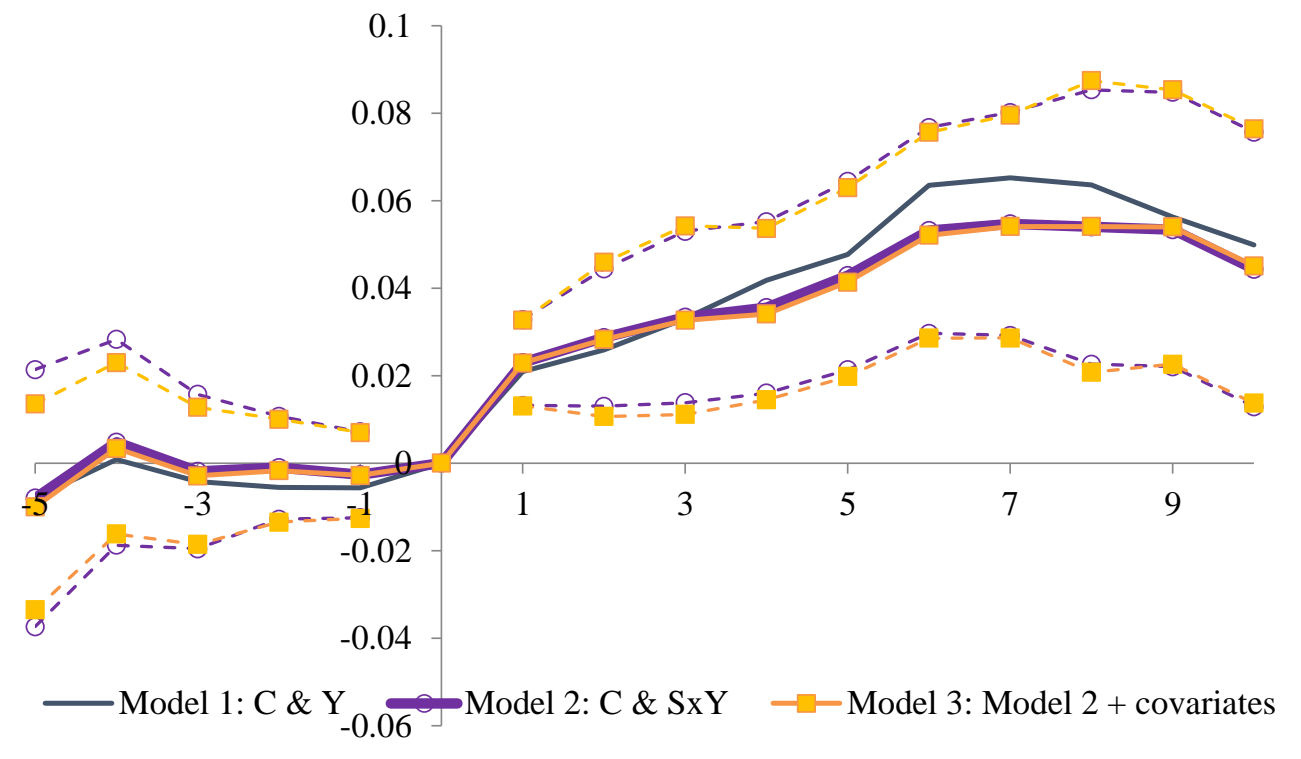

Figure 5. Estimate of the Effects of LSP on Log Property and Violent Crime

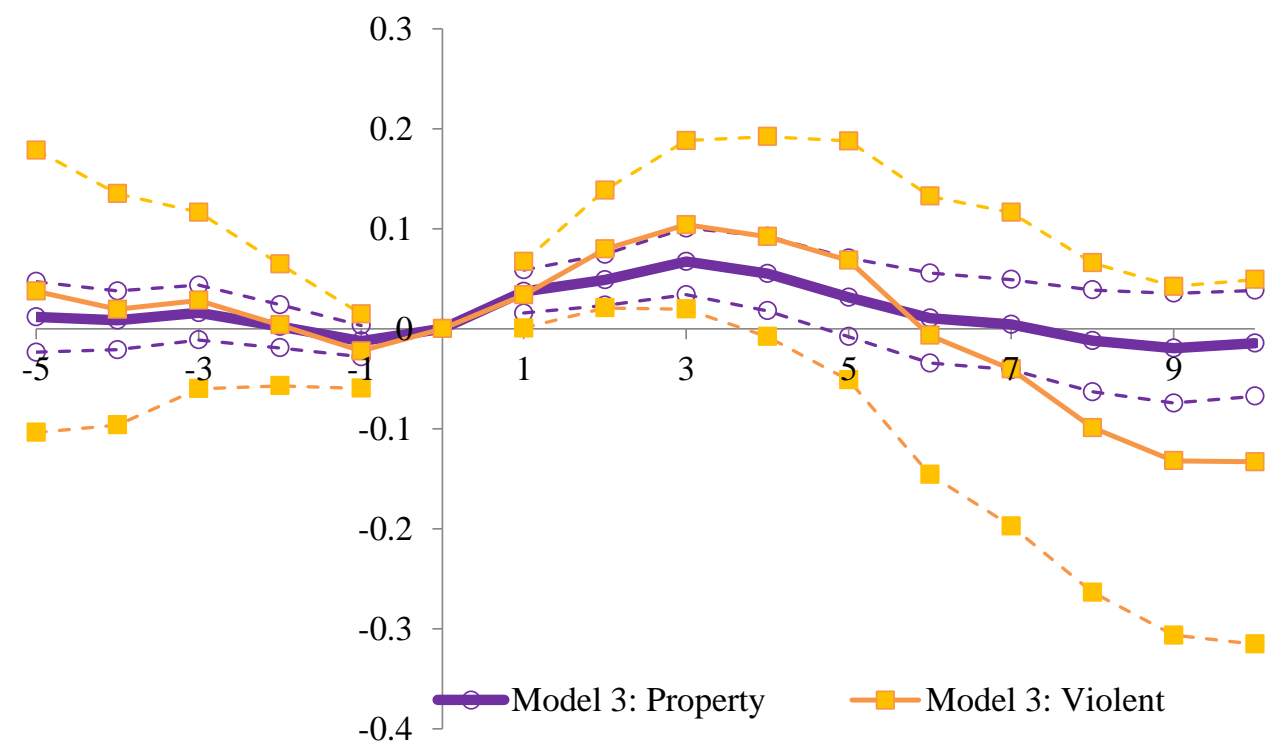

Figures 4 \& 5: Model 1 includes City, C, and year, Y, effect. Model 2 include city and state-byyear, S-Y, effects. Model 3 adds covariates from county and city data book, X, to model 2.

Covariates include median household income, percentage of population under age of 5, percentage of the population over the age of 64, percentage of population nonwhite, and the percentage of population with 12 or more years of education, which are from the decennial census.

Heteroskedasticity-robust standard errors clustered by city are presented for model $2 \& 3$. Each regression is weighted by 1985 population and excludes New York, Chicago, and Los Angeles. 
Figure 6. Estimates of the Effects of Legal Services Grants on Log Crime Per 100,000 Residents

A. Murder
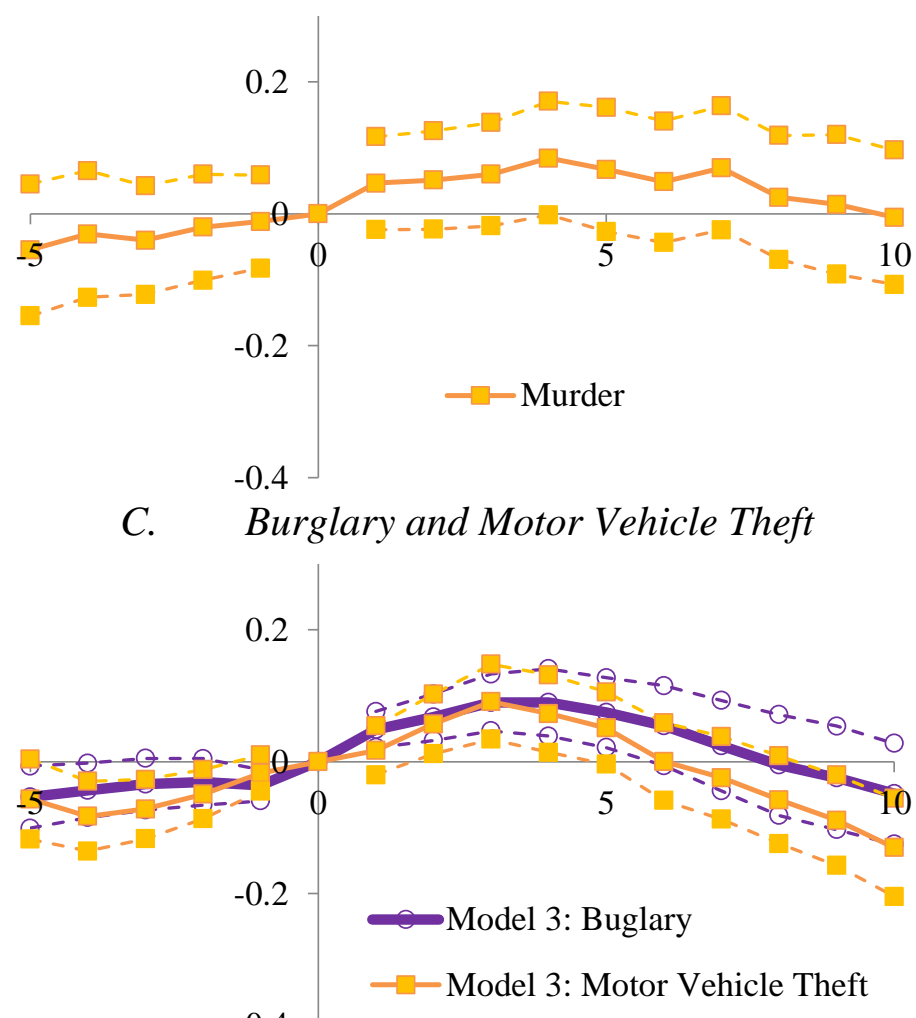

B. Rapes and Robbery

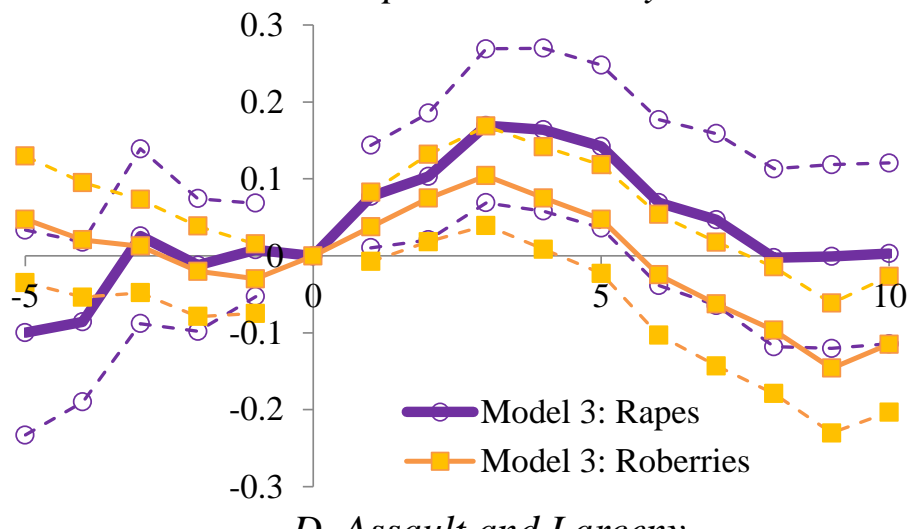

D. Assault and Larceny

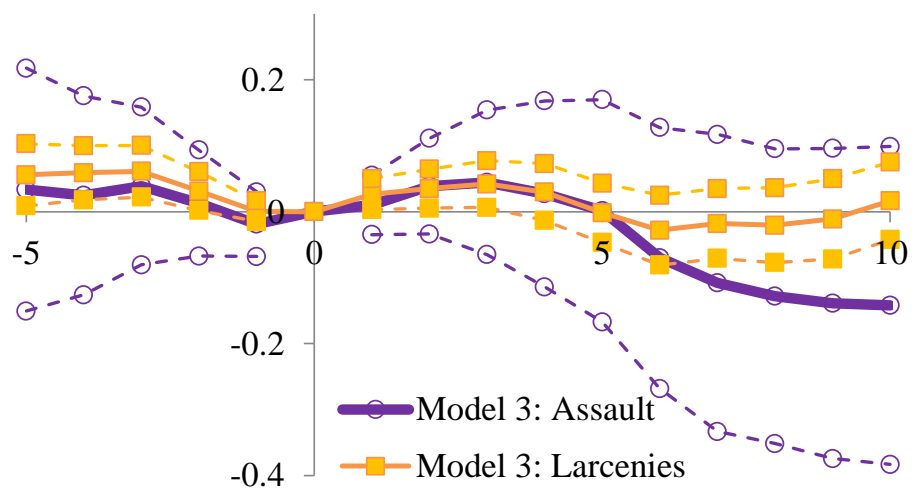

Notes: Regression analysis include city and state-by-year fixed effects as well as median household income, percentage of population under age of 5, percentage of the population over the age of 64, percentage of the non-white population, and the percentage of population with 12 or more years of education, which are from the decennial census. Heteroskedasticity-robust standard errors clustered by city are presented. Each regression is weighted by the 1985 population and excludes New York, Chicago, and Los Angeles. 
Table 1. Characteristics of Cities from 1960

\begin{tabular}{|c|c|c|c|}
\hline A. 1960 City Characteristics & $\begin{array}{l}\text { All Cities } \\
(\mathrm{N}=606)\end{array}$ & $\begin{array}{c}\text { Received } \\
\text { Grant from } \\
1965-1975 \\
(\mathrm{~N}=208)\end{array}$ & $\begin{array}{l}\text { Non-Grants } \\
\text { Cities } \\
(\mathrm{N}=398)\end{array}$ \\
\hline \multicolumn{4}{|l|}{ Means } \\
\hline Population & 98,515 & 190,585 & 50,397 \\
\hline Population per square mile & 6,662 & 7,525 & 4,958 \\
\hline Median Income & 6,004 & 5,868 & 6,273 \\
\hline \multicolumn{4}{|l|}{ Proportion of population in cities } \\
\hline in Northeast & 22.0 & 23.7 & 18.6 \\
\hline in Midwest & 30.7 & 29.6 & 33.0 \\
\hline in South & 29.9 & 28.7 & 32.2 \\
\hline in West & 17.4 & 18.0 & 16.2 \\
\hline \multicolumn{4}{|l|}{ Proportion of residents } \\
\hline men between 15 and 24 years of age & 6.6 & 6.5 & 6.7 \\
\hline men between 25 and 39 years of age & 10.0 & 10.0 & 10.0 \\
\hline Nonwhite & 12.9 & 14.4 & 10.1 \\
\hline with 12 years of education & 43.2 & 41.5 & 46.7 \\
\hline
\end{tabular}

Source: Table displays weighted averages from the 1960 Decennial Census. Census data from 1962 County and City Data Book publicly available at the ICPSR. 
Table 2. Summary Statistics for UCR Data

\begin{tabular}{lrrr}
\hline Criminal Offenses & & $\begin{array}{c}\text { Received } \\
\text { Grant from }\end{array}$ & $\begin{array}{c}\text { Non-Grants } \\
\text { Cities }\end{array}$ \\
$1960-1964$ & $\begin{array}{c}\text { All Cities } \\
(\mathrm{N}=606)\end{array}$ & $\begin{array}{c}1965-1975 \\
(\mathrm{~N}=208)\end{array}$ & \begin{tabular}{c}
$\mathrm{N}=398)$ \\
\hline Mean Per 100,000 Residents
\end{tabular} \\
Violent Crimes & 222 & 505 & 59 \\
Murder & 10 & 23 & 4 \\
Rape & 13 & 25 & 6 \\
Assault & 110 & 252 & 35 \\
Robbery & 82 & 205 & 17 \\
Property Crime & 2,829 & 5,891 & 1,230 \\
Burglary & 724 & 1,543 & 295 \\
Larceny & 1,773 & 3,585 & 827 \\
Motor vehicle theft & 333 & 763 & 108 \\
Total & 3,041 & 6,396 & 1,288 \\
Growth from 1960 to1964 & & & \\
Violent Crimes & 0.590 & 0.644 & 0.562 \\
Property Crime & 0.294 & 0.267 & 0.308 \\
Total & 0.295 & 0.285 & 0.299 \\
\hline
\end{tabular}

Source: Table averages are from the UCR from 1960 to 1964. Criminal offenses reported in the UCR are from the Uniform Crime Report Offenses Known and Cleared. UCR data are publicly available at the ICPSR. 
Table 3. The Relationship between First Legal Services Grants and the 1960 Census Demographics

(1) (2)

Dependent Variable:

Year of first federal legal service grant

Law School in County

Medical School in County

median income

population per square mile

Proportion of residents

with 12 years of education

non-white

men between the age of 15 and 24 years of age

men between the age of 25 and 39 years of age
$-0.353-0.664 *$

[0.307] [0.345]

$-0.209-0.0757$

[0.285] [0.286]

$1.848 \quad 1.346$

[1.606] [1.608]

$-0.363-0.164$

[0.234] [0.180]

$0.369 \quad 0.702$

[0.834] [0.671]

$-0.260 \quad-0.168$

[0.193] [0.210]

$1.072 \quad 0.562$

[0.757] [0.766]

$-0.189 \quad 0.0160$

[1.967] [2.148]

Weighted

State fixed effects

$\begin{array}{cc} & \text { X } \\ X & \text { X } \\ 208 & 208\end{array}$

Observations

$0.468 \quad 0.494$

R-squared

Note: Each column reports estimates from a separate linear regression. Heteroskedasticity-robust standard errors are corrected for clustering with state and presented in brackets. Independent Variables are from the 1960 Decennial Census. Columns $1 \& 2$ use the 1960 population as weights. $* * * \mathrm{p}<0.01, * * \mathrm{p}<0.05, * \mathrm{p}<0.1$ 
Table 4. The Relationship between Legal Services and Property Values

(1)

(2)

(3)

DV: Log of Median Residential Property Value for All Home Owners

Legal Service Program

Riot

Time Since LSP Established

$$
\begin{array}{ccc}
-0.00169 & 0.0388 * * & \\
{[0.0179]} & {[0.0150]} & \\
-0.0943 * * * & -0.0421 * * & -0.0468 * * * \\
{[0.0250]} & {[0.0183]} & {[0.0166]} \\
& & 0.00357 * * * \\
& & {[0.00130]}
\end{array}
$$

The Natural Log of

Median Income

$\%$ of pop with 12 years of

education

$1.283 * * *$

$1.305 * * *$

[0.123]

[0.121]

$-0.589 * * * \quad-0.614 * * *$

[0.0939]

[0.0922]

$\%$ of pop Nonwhite

$0.0612 *$

$0.118 * * *$

$0.122 * * *$

[0.0352]

[0.0235]

[0.0232]

$0.0740 *$

$0.106^{* * * *}$

$0.108 * * *$

[0.0417]

[0.0237]

Observations

1,818

1,818

1,818

R-squared

0.502

0.668

0.671

Number of Cities

606

606

606

Notes: Table display least-squares estimates obtained from estimating equation 2. The dependent variable is the log of the median residential property value for all home owners provided in the City and County Data Books from 1962, 1972, and 1983. Covariates are also from the City and County Data Books. Riot indicator variable is based on data from Carter and Margo (2007). All regressions include year fixed effects. Heteroskedasticity-robust standard errors clustered by city are presented beneath each estimate in brackets. Each regression is weighted by 1985 population and excludes New York, Chicago, and Los Angeles. $* * * \mathrm{p}<0.01, * * \mathrm{p}<0.05, * \mathrm{p}<0.1$ 
Table 5. Event Study Estimates for Log of Total Crime with Riot Intensity

(1) (2)

DV: Total Crime per 100,000 Residents

\begin{tabular}{|c|c|c|}
\hline \multicolumn{3}{|c|}{ Years Before Treatment } \\
\hline \multirow[t]{2}{*}{-5} & 0.00502 & 0.00558 \\
\hline & {$[0.0180]$} & {$[0.0181]$} \\
\hline \multirow[t]{2}{*}{-4} & 0.00439 & 0.00487 \\
\hline & {$[0.0153]$} & {$[0.0153]$} \\
\hline \multirow[t]{2}{*}{-3} & 0.0119 & 0.0119 \\
\hline & {$[0.0145]$} & {$[0.0146]$} \\
\hline \multirow[t]{2}{*}{-2} & -0.00381 & -0.00397 \\
\hline & {$[0.0117]$} & {$[0.0118]$} \\
\hline \multirow[t]{2}{*}{-1} & $-0.0157 *$ & $-0.0150^{*}$ \\
\hline & {$[0.00837]$} & {$[0.00858]$} \\
\hline \multicolumn{3}{|c|}{ Years After Treatment } \\
\hline \multirow[t]{2}{*}{1} & $0.0381 * * *$ & $0.0328 * * *$ \\
\hline & {$[0.0111]$} & {$[0.0118]$} \\
\hline \multirow[t]{2}{*}{2} & $0.0528 * * *$ & $0.0515^{* * *}$ \\
\hline & {$[0.0125]$} & {$[0.0125]$} \\
\hline \multirow[t]{2}{*}{3} & $0.0724 * * *$ & $0.0719 * * *$ \\
\hline & {$[0.0166]$} & {$[0.0168]$} \\
\hline \multirow[t]{2}{*}{4} & $0.0611 * * *$ & $0.0611^{* * *}$ \\
\hline & {$[0.0188]$} & {$[0.0189]$} \\
\hline \multirow[t]{2}{*}{5} & $0.0414 * *$ & $0.0414 * *$ \\
\hline & {$[0.0201]$} & {$[0.0202]$} \\
\hline \multirow[t]{2}{*}{6} & 0.0216 & 0.0217 \\
\hline & {$[0.0224]$} & {$[0.0224]$} \\
\hline \multirow[t]{2}{*}{7} & 0.0154 & 0.0155 \\
\hline & {$[0.0234]$} & {$[0.0234]$} \\
\hline \multirow[t]{2}{*}{8} & 0.000119 & 0.000154 \\
\hline & {$[0.0257]$} & {$[0.0257]$} \\
\hline \multirow[t]{2}{*}{9} & -0.00746 & -0.00747 \\
\hline & {$[0.0278]$} & {$[0.0278]$} \\
\hline \multirow[t]{2}{*}{10} & -0.00191 & -0.00192 \\
\hline & {$[0.0272]$} & {$[0.0272]$} \\
\hline \multirow{2}{*}{\multicolumn{2}{|c|}{ Riot Intensity }} & $0.00202 * * *$ \\
\hline & & {$[0.000623]$} \\
\hline Observations & 15,756 & 15,756 \\
\hline R-squared & 0.887 & 0.887 \\
\hline Number of cities & 606 & 606 \\
\hline
\end{tabular}

Notes: Table display weighted least-squares estimates obtained from estimating equation 1. Column 1 corresponds to model 3. Column 2 includes a Riot intensity variable is based on data from Carter and Margo (2007). Heteroskedasticity-robust standard errors clustered by city are presented beneath each estimate in brackets. . *** $\mathrm{p}<0.01, * * \mathrm{p}<0.05, * \mathrm{p}<0.1$ 
Table 6. Event Study Estimates for Log of Total Crime by OEO Grant

(1)

(2)

(3)

DV: Log of Total Crime per 100,000 Residents

\begin{tabular}{|c|c|c|c|}
\hline \multicolumn{4}{|c|}{ Years Before Treatment } \\
\hline \multirow[t]{2}{*}{-5} & 0.0275 & 0.0373 & 0.00502 \\
\hline & [0.0242] & {$[0.0223]$} & {$[0.0180]$} \\
\hline \multirow[t]{2}{*}{-4} & 0.0242 & 0.0217 & 0.00439 \\
\hline & {$[0.0205]$} & {$[0.0185]$} & {$[0.0153]$} \\
\hline \multirow[t]{2}{*}{-3} & 0.0169 & 0.0151 & 0.0119 \\
\hline & {$[0.0163]$} & {$[0.0155]$} & {$[0.0145]$} \\
\hline \multirow[t]{2}{*}{-2} & 0.0108 & 0.0155 & -0.00381 \\
\hline & {$[0.0118]$} & {$[0.0116]$} & {$[0.0117]$} \\
\hline \multirow[t]{2}{*}{-1} & -0.00136 & -0.00300 & $-0.0157 *$ \\
\hline & {$[0.00782]$} & {$[0.00725]$} & {$[0.00837]$} \\
\hline \multicolumn{4}{|c|}{ Years After Treatment } \\
\hline \multirow[t]{2}{*}{1} & 0.00401 & -0.00713 & $0.0381 * * *$ \\
\hline & {$[0.00744]$} & {$[0.00752]$} & [0.0111] \\
\hline \multirow[t]{2}{*}{2} & 0.00998 & -0.00137 & $0.0528 * * *$ \\
\hline & [0.0119] & {$[0.0112]$} & [0.0125] \\
\hline \multirow[t]{2}{*}{3} & 0.0149 & 0.00741 & $0.0724 * * *$ \\
\hline & {$[0.0153]$} & {$[0.0146]$} & [0.0166] \\
\hline \multirow[t]{2}{*}{4} & 0.0224 & 0.00868 & $0.0611 * * *$ \\
\hline & [0.0191] & [0.0182] & {$[0.0188]$} \\
\hline \multirow[t]{2}{*}{5} & 0.0249 & 0.00600 & $0.0414 * *$ \\
\hline & [0.0224] & {$[0.0210]$} & {$[0.0201]$} \\
\hline \multirow[t]{2}{*}{6} & 0.0264 & -0.00233 & 0.0216 \\
\hline & {$[0.0248]$} & {$[0.0235]$} & {$[0.0224]$} \\
\hline \multirow[t]{2}{*}{7} & 0.0141 & -0.0114 & 0.0154 \\
\hline & {$[0.0266]$} & {$[0.0257]$} & {$[0.0234]$} \\
\hline \multirow[t]{2}{*}{8} & 0.00125 & -0.0249 & 0.000119 \\
\hline & {$[0.0286]$} & [0.0276] & {$[0.0257]$} \\
\hline \multirow[t]{2}{*}{9} & -0.00722 & -0.0327 & -0.00746 \\
\hline & {$[0.0300]$} & {$[0.0287]$} & {$[0.0278]$} \\
\hline \multirow[t]{2}{*}{10} & 0.000896 & -0.0404 & -0.00191 \\
\hline & {$[0.0314]$} & [0.0299] & {$[0.0272]$} \\
\hline OEO Grants & Head Start & CAA & LSP \\
\hline Observations & 15,756 & 15,756 & 15,756 \\
\hline R-squared & 0.858 & 0.858 & 0.887 \\
\hline Number of cities & 606 & 606 & 606 \\
\hline
\end{tabular}

Notes: Table displays least-squares estimates obtained from estimating equation 1. Column 1 uses the first Head-Start Grant as the event while Columns 2 and 3 uses the first Community Action Agency and Legal Services Program as the event respectively. $* * * p<0.01, * * p<0.05, * \mathrm{p}<0.1$ 